\title{
ПРОФЕСІЙНА КОМПЕТЕНТНІСТЬ КЕРІВНИКА ЗАКААДУ ОСВІТИ У ВИМІРІ СУЧАСНИХ ОСВІТНІХ ТРАНСФОРМАЦІЙ
}

У статті досліджено професійні компетентності керівника закладу освіти у вилірі сучасних освітніх трансформацій.

Автори статті проаналізували основні напрями професійної діяльності керівника закладу освіти, визначені Законом Украйни «Про освіту»; перелік професійних компетентностей $і$ зміст трудових функцій керівника закладу освіти відповідно до професійного стандарту «Керівник (директор) закладу загальної середньої освіти». Визначено, що ефективність забезпечення виконання управлінських завдань освіти уможливлюеться системою професійних компетентностей, визначених професійним стандартом. У дослідженнях українських учених також наголошується на важливості формування методологічної і фасихітативної компетентностей.

Дослідження кращчих світових практик організації̈ управлінської діяльності свідчить про багатоаспектність професійної діяльності менеджера у фінській системі освіти: педагогічне управління школою, професійне ухвалення рішень у межах чинного нормативно-правого законодавства, стратегічне управління як умова довгострокової узгодженості шкільної роботи, фінансовий менеджмент, господарський менеджмент, створення безпечного освітнвого середовища, участь у розвитку національної освітньої політики, планування діяльності закладу освіти із залученням учасників освітнього процесу. Вирізняльними особливостяли управлінської діяльності в освітній системі Сінгапуру є реалізаціл принципу конкурентної співпраці, забезпечення балансу підзвітності і відповідальності, горизонтальна професійна мобільність керівників закладів освіти.

У статті зроблено висновок про те, що в закордонних освітніх системах позитивною рисою є глобалізація управлінської діяльності, що передбачає проєктування впливу управлінських рішень на локальному шкільному рівні на інші заклади освіти і розвиток країни в цілому та досвід реалізації системного залучення керівників закладів освіти до формування національної освітньої політики.

Ключові слова: менеджер освіти, професійна компетентність, управління, світові управлінські практики.

Постановка проблеми. Національна система освіти на початку третього тисячодіття характеризується зміною освітньої парадигми, оновленням змісту та технологій навчання. У зв'язку з цим актуалізується проблема підготовки сучасних менеджерів освіти до управління у вимірі нових освітніх трансформацій.

Актуальність проблеми розвитку професійної компетентності менеджерів освіти пояснюється потребою в розв'язанні протиріччя, яке виникдо між сучасними вимогами до професійної діяльності менеджера освіти як цілісної особистості, суб'єкта освітнього процесу, здатного до саморозвитку, конструювання й упровадження гуманістичних 
педагогічних систем і технологій та реальним рівнем його професійної компетентності в розв'язанні освітніх завдань, ухваленні управлінських рішень. Саме менеджери освіти мають стати рушійною силою відродження та створення якісно нової національної освіти.

Аналіз досліджень. Серед основних досліджень, у яких розкрито питання професійної компетентності менеджерів освіти та їхньої управлінської діяльності, доцільно відзначити праці І. Боднар, В. Громового, Є. Павдютенкова, А. Покка, Т. Сорочан, Ї. Трунди, В. Ястребової та інших освітніх менеджерів і науковців.

Метою статті є аналіз професійної компетентності керівника закладу освіти у вимірі сучасних освітніх трансформацій.

Виклад основного матеріалу. У сучасному розумінні менеджер освіти це професіонал-управлінець, який здійснюе організацію і координацію діяльності колективу на науковій основі. Саме на нього покладається відповідальність за розроблення, ухвалення й виконання рішень, спрямованих на забезпечення ефективного виконання завдань, які стоять перед педагогами і закладом освіти.

Головними завданнями менеджера будь-якого рівня та в будь-якій організації є визначення мети управління, стимулювання, комунікація й контроль. Управління передбачає виконання таких функцій, як планування, організація, координація, мотивація, контроль та інших, що забезпечує умови для продуктивної й ефективної праці зайнятих в організації працівників і отримання результатів, які б відповідади поставленим цілям. Водночас варто наголосити, що спрямованість управлінської діяльності керівника закладу освіти е педагогічною за своєю сутністю, адже навіть тоді, коди керівник розв'язує господарські або фінансові завдання, він робить це, маючи на увазі досягнення кінцевої педагогічної мети.

3 огляду на це професійна діяльність керівника закладу освіти характеризується такими особливостями:

- результати управлінської діяльності відтерміновані в часі, мають суспільно важдиве значення і виражаються опосередковано в показниках якості освітньої діяльності;

- предметом управлінської діяльності є інформація і суб'єкти освітнього процесу (різного віку та соціального статусу, з гендерним дисбалансом);

- широкоаспектний зміст управдінської діядьності (педагогічна, економічна, господарська тощо) [2, с. 124-127].

У контексті реформування національної системи освіти: реалізації Закону України «Про освіту», Концепції Нової української школи, що передбачають збільшення автономії закдаду освіти та академічної свободи вчителя, змінюються вимоги до професійних якостей керівника закладу освіти. Професійна компетентність менеджера обумовдюе ефективність його дій не тільки в освітній діяльності, а й в управлінській, фінансово-економічній, адміністративно-господарській, проєктній, інноваційній тощо. Сучасний менеджер освіти має вододіти гдибокими теоретичними знаннями й практичними вміннями, продукувати та реалізовувати інновації, бути професійно компетентним. Зміст професійної компетентності керівника закладу освіти визначається як сукупність систематичних науково-філософських, суспільнополітичних, психолого-педагогічних, предметних та спеціально-функціональних знань і вмінь, відповідних особистісних якостей, необхідних для ефективної професійної діяльності [1].

У Законі України «Про освіту» визначено основні напрями діяльності керівника закладу освіти:

- «...організовує діяльність закладу освіти; 
- вирішує питання фінансово-господарської діяльності закладу освіти;

- призначає на посаду та звільняє 3 посади працівників, визначає їхні функціональні обов'язки;

- забезпечуе організацію освітнього процесу та здійснення контролю за виконанням освітніх програм;

- забезпечуе функціонування внутрішньої системи забезпечення якості освіти;

- забезпечує умови для здійснення дієвого та відкритого громадського контродю за діяльністю закладу освіти;

- сприяє та створюе умови для діяльності органів самоврядування закладу освіти;

- сприяе здоровому способу життя здобувачів освіти та працівників закдаду освіти;

- забезпечуе створення у закладі освіти безпечного освітнього середовища, вільного від насильства та булінгу (цькування)...» [5].

Ухвалення Закону України «Про освіту» змінюе освітню парадигму, розширюе й видозмінюе зміст і механізми управдінської діяльності, а відтак зумовлюе оновлення змісту професійних компетентностей керівника закладу освіти, який має забезпечити реалізацію автономії закладу освіти (фінансову, академічну, кадрову та організаційну) та передбачає здійснення таких видів менеджменту: організаційного, освітнього, фінансово-господарського, кадрового, системи якості.

На законодавчому рівні перелік професійних компетентностей і зміст трудових функцій керівника закладу загальної середньої освіти визначено у професійному стандарті «Керівник (директор) закладу загальної середньої освіти»:

- нормативно-правова компетентність;

- компетентність стратегічного управління закдадом освіти;

- компетентність стратегічного управління персоналом;

- компетентність забезпечення якості освітньої діяльності та функціонування внутрішньої системи забезпечення якості освіти;

- компетентність організації діяльності закладу освіти на засадах зовнішньої системи забезпечення якості освіти;

- лідерська компетентність;

- емоційно-етична компетентність;

- компетентність педагогічного, соціального та мережевого партнерства;

- здоров'язбережувальна компетентність;

- інклюзивна компетентність;

- проєктувальна компетентність;

- інноваційна компетентність;

- здатність до навчання впродовж життя;

- інформаційно-цифрова компетентність [6].

Аналіз визначених у професійному стандарті компетентностей і змісту трудових функції свідчить про їх кореляцію з напрямами діяльності керівника закладу освіти, визначеними в Законі України «Про освіту».

У процесі формування і розвитку професійних компетентностей менеджерів освіти у вимірі сучасних освітніх трансформацій актуалізуються результати наукового пошуку сучасних українських учених. У дослідженні управлінської діяльності О. Мармаза на основі аналізу посадових вимог до керівників (професійних, кваліфікаційних, соціально-психологічних) визначає функціональну компетентність керівника як систему знань та умінь: методологічних, нормативних, змістових, управлінських, педагогічних, психодогічних, соціально-правових, фінансовоекономічних [2, с. 142]. 
Результати дослідження особливостей професійної діяльності менеджерів освіти, проведеного Т. Сорочан, показали, що професіоналізм управлінської діяльності є сукупністю компетенцій (функційної, соціально-педагогічної, соціально-економічної, інноваційної, фасилітативної), що дають змогу керівникові школи професійно здійснювати управлінську діяльність у сучасних соціально-економічних умовах з урахуванням особливостей об'єкта управління, пов'язаних з розв'язанням педагогічних завдань (із навчанням, вихованням і розвитком особистості учня) [7, с. 171-172].

Конструктивний пошук шляхів підвищення якості управлінської діяльності, iï організації відповідно до вимог нормативно-правових документів, пріоритетів розвитку національної системи освіти актуалізуе дослідження кращих світових практик з метою імплементації конструктивного досвіду в сучасну освітню галузь.

Дослідження фінського досвіду управління освітніми закладами свідчить про зміну парадигми від управління соціальними зв'язками й розвитку інтелектуального капіталу до педагогічного керування освітньою екосистемою закладу освіти з урахуванням фінансових мождивостей, забезпечуючи якість навчання. 3 огляду на це основними пріоритетами професійної діяльності менеджера у фінській системі освіти є:

- педагогічне управління школою (визначення цілей та їх імплементація у стратегічний план закладу освіти; кадровий менеджмент задля створення унікадьної шкільної культури; створення умов для реалізації академічної свободи вчителя щодо досягнення цілей установи; забезпечення реалізації Національного основного навчального плану та вдосконалення місцевого навчального плану; розвиток культури довіри до вчительської праці);

- професійне ухвалення рішень у межах чинного нормативно-правого законодавства (щодо учнів - приймання й відрахування, об'єктивність оцінювання відповідно до навчального плану; щодо вчителів - приймання і звільнення, контродь і дисциплінарні заходи, професійний розвиток);

- стратегічне управління як умова довгострокової узгодженості шкільної роботи (залучення шкільної спільноти до визначення стратегічних цілей для розвитку школи і забезпечення благополуччя учнів);

- фінансовий менеджмент (планування шкільного бюджету, проведення тендерних процедур, ухвалення фінансових рішень щодо функціонування закладу освіти в умовах наявного бюджету без зниження окості освіти);

- господарський менеджмент (забезпечення безпечних умов перебування у закладі освіти, будівництво та ремонт шкільних приміщень, технічне обслуговування і прибирання будівель і територій);

- створення безпечного освітнього середовища (розроблення шкільного плану щодо безпечних умов, формування культури безпеки закладу освіти, організація навчань та тренувань 3 питань безпеки, піклування про життеві ситуації здобувачів освіти і педагогів);

- участь у розвитку національної освітньої політики (участь у референтних групах з обговорення освітньої політики, прогнозування позитивних і негативних наслідків запланованих реформ);

- планування діяльності закладу освіти із залученням учасників освітнього процесу (документування основних цілей навчального року на основі стратегічних цілей розвитку школи, організації освітнього процесу, роботи з педагогічними працівниками, розвитку керівництва та реалізації міжнародних проєктів) [4, с. 50-80].

Аналіз основних напрямів професійної діяльності менеджерів у фінській системі освіти надає мождивість зробити висновок, що для успішного управління закладом us 158 
освіти у керівника мають бути сформовані нормативно-правові, педагогічні, стратегічні, господарські компетентності. Це дасть змогу організувати діядьність закдаду освіти відповідно до пріоритетів національної освітньої політики, урахувати інтереси всіх учасників освітнього процесу і забезпечити якість освіти.

Ураховуючи високі результати міжнародних досліджень якості освіти Сінгапуру, доцільно розглянути вирізняльні особливості управлінської діяльності в освітній системі цієї країни.

Реалізація принципу конкурентної співпраці формує у керівників глобалізацію управлінської діяльності, що передбачає проєктування впливу управлінських рішень на локальному шкільному рівні на інші заклади освіти і розвиток країни в цілому.

Забезпечення балансу підзвітності і відповідальності. Зокрема, рушійною силою конкурентності є підзвітність, а співпраці - відповідальність.

Горизонтальна професійна мобільність керівників шкіл надає можливість поширювати найкращі управлінські практики в різних школах, розвинути професійні компетентності в умовах нових викликів [5, с. 126].

Висновки. У контексті реформування національної системи освіти професійна компетентність менеджера обумовлює ефективність його дій у освітній, управлінській, фінансово-економічній, адміністративно-господарській, проєктній, інноваційній діяльності тощо. Зміст професійної діяльності керівника закладу освіти визначено у Законі України «Про освіту». Ефективність забезпечення виконання основних напрямів управлінської діяльності умождивлюється системою професійних компетентностей, визначених професійним стандартом. У дослідженнях українських учених також нагодошується на важдивості формування метододогічної і фасилітативної компетентностей.

Дослідження кращих світових практик організації управлінської діяльності свідчить про багатоаспектність професійної діядьності менеджера у фінській системі освіти: педагогічне управління школою, професійне ухвалення рішень у межах чинного нормативно-правого законодавства, стратегічне управдіння як умова довгострокової узгодженості шкільної роботи, фінансовий менеджмент, господарський менеджмент, створення безпечного освітнього середовища, участь у розвитку національної освітньої політики, планування діяльності закладу освіти із залученням учасників освітнього процесу. Вирізняльними особливостями управлінської діяльності в освітній системі Сінгапуру є реалізація принципу конкурентної співпраці, забезпечення балансу підзвітності і відповідальності, горизонтальна професійна мобільність керівників закладів освіти. Слід зазначити, що у закордонних освітніх системах позитивною рисою є глобалізація управлінської діяльності, що передбачає проєктування впдиву управлінських рішень на локальному шкільному рівні на інші заклади освіти і розвиток країни в цілому та досвід реалізації системного залучення керівників закладів освіти до формування національної освітньої політики.

Здійснений аналіз не вичерпуе всіх аспектів досліджуваної проблеми і засвідчуе необхідність подальшого вивчення наукових основ управлінської діяльності та світового досвіду щодо змісту професійної діядьності освітніх менеджерів з метою підвищення якості освіти.

\section{Список використаних джерел:}

1. Жорова І. Я. Професійний розвиток менеджерів освіти нової генерації. Сучасні проблеми підготовки та професійного удосконалення працівників сфери освіти: тези VII Міжнародної науково-практичної конференції (23 квітня 2021 року, м. Чернігів) / упорядн. Н. О. Терентьєва. Черкаси: Видавець Чабаненко Ю. В., 2021. С. 42-46. 
2. Мармаза О. І. Менеджмент в освіті: дорожня карта керівника. Харків: Видав. група «Основа», 2007. 448 с. (Серія «Адміністратору школи»).

3. Пак Т. И. Переймаючи досвід Сінгапуру. Сила парадоксів / пер. з ангд. О. М. Назарової. Харків : Ранок, 2019. 208 с.

4. Покка Арі. Вищий клас. Шкільне управління по-фінськи / пер. 3 англ. О. М. Назарової. 2-ге вид., випр. Харків : Ранок, 2019. 169 с.

5. Про освіту: Закон України від 05.09.2017 p. № 2145-VIII. URL: https://zakon.rada.gov.ua/laws/show/2145-19\#n401

6. Про затвердження професійного стандарту «Керівник (директор) закладу загальної середньої освіти»: затверджено наказом Міністерства економіки України від 17.09.2021 p. № 568-21. URL: $\quad$ https://mon.gov.ua/storage/app/media/news/2021/09/22/Nakaz-568zatverdzh.standartu.keriv.22.09.pdf.

7. Сорочан Т. М. Підготовка керівників шкіл до управлінської діяльності: теорія та практика: монографія. Ауганськ: Знання, 2005. 384 с.

\section{References:}

1. Zhorova, I. Ya. (2021). Profesiinyi rozvytok menedzheriv osvity novoi heneratsii [Professional development of new generation education managers], Suchasni problemy pidhotovky ta profesiinoho udoskonalennia pratsionykiv sfery osvity, tezy VII Mizhnarodnoi naukovo-praktychnoi konferentsii [Modern problems of training and professional development of education workers, Abstracts of the VII International Scientific and Practical Conference]. Cherkasy: Vydavets Chabanenko Yu. V. [in Ukrainian].

2. Marmaza, O. I. (2007). Menedzhment v osviti: dorozhnia karta kerivnyka [Management in education: a road map of the head]. Kharkiv: Osnova [in Ukrainian].

3. Pak, T. Y. (2019). Perejmajuchy dosvid Singhapuru. Syla paradoksiv [Taking the Experience of Singapore. The Power of Paradoxes]. (O. M. Nazarovoi, Trans.). Kharkiv: Ranok [in Ukrainian].

4. Pokka, A. (2019). Vyshchyi klas. Shkilne upravlinnia po-finsky [Top Class, Finnish School Leadership and Management]. (O. M. Nazarovoi, Trans.). Kharkiv: Ranok [in Ukrainian].

5. On education, Law of Ukraine dated September, 5, 2017, No. 2145-VIII. Retrieved from https://zakon.rada.gov.ua/laws/show/2145-19\#n401 [in Ukrainian].

6. On approval of the professional standard "Head (director) of a general secondary education institution", Order of the Ministry of Economy of Ukraine dated September, 17, 2021, No. 568-21. Retrieved from https://mon.gov.ua/storage/app/media/news/2021/09/22/Nakaz-568zatverdzh.standartu.keriv.22.09.pdf [in Ukrainian].

7. Sorochan, T. M. (2005). Pidhotovka kerivnykiv shkil do upravlinskoi diialnosti: teoriia ta praktyka [Preparation of school leaders for managerial activity: theory and practice]. Luhansk: Znannia [in Ukrainian].

Zhorova I. Ya., orcid.org/0000-0003-4304-4962

Kuzmenko V. V., orcid.org/0000-0002-5424-8234

\section{PROFESSIONAL COMPETENCE OF THE HEAD OF THE EDUCATIONAL INSTITUTION IN THE MEASUREMENT OF MODERN EDUCATIONAL TRANSFORMATIONS}

The article examines the professional competencies of the head of an educational institution in measuring modern educational transformations.

The authors of the article analyzes the main areas of professional activity of the head of the educational institution, defined by the Law of Ukraine "On Education"; the list of professional competencies and the content of labor functions of the head of the educational institution in accordance with the professional standard "Head (director) of the institution of general secondary education". It is determined that the effectiveness of ensuring the implementation of managerial tasks of education 
is made possible by the system of professional competencies defined by the professional standard. The research of Ukrainian scientists also emphasizes the importance of forming methodological and facilitative competencies.

A study of the world's best practices in the organization of management shows the diversity of professional activities of managers in the Finnish education system: pedagogical school management, professional decision-making under current legislation, strategic management as a condition of longterm coherence of school work, financial management, economic management educational environment, participation in the development of national educational policy, planning the activities of educational institutions with the involvement of participants in the educational process. Distinctive features of management activities in the educational system of Singapore are the implementation of the principle of competitive cooperation, ensuring a balance of accountability and responsibility, horizontal professional mobility of heads of educational institutions.

The article concludes that the globalization of management is positive in foreign educational systems, which involves designing the impact of management decisions at the local school level on other educational institutions and the development of the country as a whole and the experience of systematic involvement of heads of educational institutions in national education policy.

Key words: education manager, professional competence, management, world management practices.

Дата надходження статті: 12.11.2021 p.

Рецензент: доктор педагогічних наук, доцент Рябуха I. М.

У, ДК 371.14-373.07

DOI https://doi.org/10.37915/pa.vi50.319

Кохановська О. В. , orcid.org/0000-0001-7294-173X Довгий О. Я. orcid.org/0000-0002-9718-344

\section{МАРКЕТИНГОВА КОМПЕТЕНТНІСТЬ КЕРІВНИКІВ ЗАКААДІВ ОСВІТИ: МОЖАИВОСІ РОЗВИТКУ В УМОВАХ ПІСДЯДИПЛОМНОЇ ОСВІТИ}

У статті проаналізовано можливості розвитку маркетингової компетентності керівників закладів освіти в умовах післядипломної освіти. Акцентовано, щзо свогодні освітні заклади функціонують у ринкових конкурентних умовах, що безпосередньо впливає на формування та оновлення переліку освітніх послуг, побудову партнерських взаємовідносин між освітньою організацієєю та громадськістю, формування іліджу закладу освіти, розвиток інноваційного потенцііалу та створення позитивного внутрішнього клімату. Це вимагае управління освітньою установою з точки зору маркетингового підходу $i$ є одним із завдань сучасного менеджера. Для впровадження нових підходів до управління керівник освітньої установи повинен володіти відповідними професійно-особистісними характеристиками. Однією з них є його маркетингова компетентність.

Схарактеризовано вимоги до сучасних керівників закладів загальної середньої та дошкільної освіти в контексті відповідних професійних стандартів, щя надае змогу встановити необхідність оволодіння директорами освітніх установ маркетинговими знаннями, уміннями та навичками.

*(C) Кохановська О. В.

*(C) Довгий О. Я.

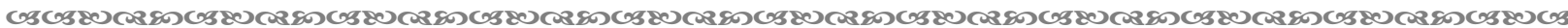

